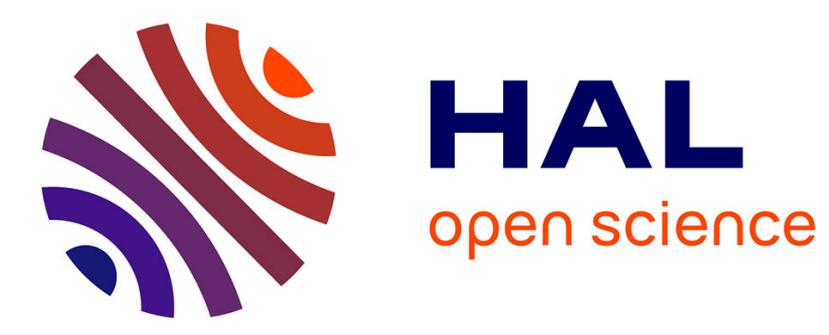

\title{
Molecular strategies to enhance the genetic resistance of grapevines to powdery mildew
}

\author{
I.B. Dry, A. Feechan, C. Anderson, A.M. Jermakow, A Bouquet, \\ Anne-Francoise A.-F. Adam-Blondon, Mr Thomas
}

\section{To cite this version:}

I.B. Dry, A. Feechan, C. Anderson, A.M. Jermakow, A Bouquet, et al.. Molecular strategies to enhance the genetic resistance of grapevines to powdery mildew. 8. International Symposium on Grapevine Physiology and Biotechnology, Nov 2008, Adelaide, Australia. hal-02820221

\section{HAL Id: hal-02820221 https://hal.inrae.fr/hal-02820221}

Submitted on 6 Jun 2020

HAL is a multi-disciplinary open access archive for the deposit and dissemination of scientific research documents, whether they are published or not. The documents may come from teaching and research institutions in France or abroad, or from public or private research centers.
L'archive ouverte pluridisciplinaire HAL, est destinée au dépôt et à la diffusion de documents scientifiques de niveau recherche, publiés ou non, émanant des établissements d'enseignement et de recherche français ou étrangers, des laboratoires publics ou privés. 


\title{
Molecular strategies to enhance the genetic resistance of grapevines to powdery mildew
}

\author{
I.B. DRY', A. FEECHAN', C. ANDERSON',2, A.M. JERMAKOW', A. BOUQUET ${ }^{3}$, \\ A.-F. ADAM-BLONDON ${ }^{4}$ and M.R. THOMAS \\ 'CSIRO Plant Industry, PO Box 350, Glen Osmond SA 5064, Australia \\ ${ }^{2}$ Current address: School of Forest Resources and Conservation, University of Florida, Gainesville, FL 326I I, USA \\ ${ }^{3}$ UMR BEPC, Campus Agro-M/INRA, 2 place Viala, 34060, Montpellier, France \\ ${ }^{4}$ INRA-URGV 2, rue Gaston Crémieux CP 5708 F-91057, Evry, France \\ Corresponding author: Dr lan B.Dry, fax+6I 8 8303860I, email ian.dry@csiro.au
}

\begin{abstract}
The Eurasian winegrape Vitis vinifera has little or no genetic resistance to the major fungal pathogens, powdery mildew (Erysiphe necator) and downy mildew (Plasmopora viticola). These pathogens were first introduced into French vineyards from North America in the 1800s before spreading to all major grape producing regions of the world. As a result, grape production is highly dependent on the use of fungicides. With the increasing financial and environmental costs of chemical application and the emergence of fungicide-resistant strains, the introduction of natural genetic resistance against these fungal pathogens is a high priority for viticultural industries worldwide. We are utilising a number of different molecular approaches to increase our understanding of the basis of resistance to these important major fungal pathogens and to identify potential new sources of genetic resistance. This review will outline the progress and the potential of each of these different molecular strategies to the generation of fungalresistant grapevine germplasm.
\end{abstract}

\begin{abstract}
Abbreviations
BAC bacterial artificial chromosome; BC back-cross; CC coiled-coil; CT C-terminal;

LRR leucine-rich repeat; MAMP microbe-associated molecular pattern; NBS nucleotide-binding site; PEN penetration; RGA resistance gene analogue; $\mathbf{R L K}$ receptor-like kinase; $\boldsymbol{R} \boldsymbol{p} \boldsymbol{v} \mathbf{1}$ Resistance to Plasmopora viticola 1; Run1 Resistance to Uncinula necator 1; TIR Toll/Interleukin-1 receptor
\end{abstract}

Keywords: Erysiphe necator, grapevine, MLO, powdery mildew, resistance, Runl

\section{Control of fungal diseases is a major problem for viticulture worldwide}

The world wine industry is based on cultivation of the grape species, Vitis vinifera. However, this species is highly susceptible to a number of pathogens that can cause economically devastating diseases, including powdery mildew, caused by Erysiphe necator (syn. Uncinula necator), downy mildew (Plasmopora viticola) and Botrytis bunch rot (Botrytis cinerea). From a global perspective, powdery mildew is the most important of these three pathogens because it does not require specific humidity and temperature conditions for infection, as is the case with downy mildew and Botrytis infection. Consequently, although the severity of powdery mildew infection can vary from season to season, it is a constant threat to grapegrowers. Powdery mildew infects all green grapevine tissues including the leaves, stems and berries. Severe infection can debilitate vines, reduce net photosynthesis, retard ripening and degrade wine quality
(Gadoury et al. 2001, Calonnec et al. 2004, Stummer et al. 2005). Even minor berry infections have been shown to be associated with elevated populations of spoilage microorganisms, increased infestation by insects and increased Botrytis bunch rot at harvest (Gadoury et al. 2007).

Modern grapevine cultivation relies heavily upon the use of chemical fungicides such as sulphur and sterol biosynthesis inhibitors to control this pathogen and most grapegrowers would apply between 6-10 fungicide sprays per season. In France alone, the cost of fungicides for powdery mildew control is around 75 million Euros per year (A. Bouquet, pers. comm., 2008) and this does not take into account the increasing fuel costs associated with the application of these fungicides. Furthermore, fungal strains have been reported that have evolved resistance to a number of the commonly used fungicides (Erickson and Wilcox 1997, Savocchia et al. 2004, Baudoin et al. 2008). There is also now increasing pressure by legislators to 
restrict the use of certain agrochemicals because they consider them to be detrimental to the environment and may pose a risk to human health. Indeed, the European Commission is currently considering a proposal to ban the use of a large number of agrochemicals in Europe by 2013 which are routinely used for the control of a number of fungal diseases in grapes including powdery mildew in grapes (Pesticides Safety Directorate 2008). Thus, the introduction of effective genetic resistance into winegrape cultivars to reduce the dependence of viticulture on chemical inputs would be of significant economic and environmental benefit.

Powdery mildews are obligate biotrophic pathogens, meaning that they require a living plant host for their growth and reproduction. Upon landing on the plant surface, powdery mildew spores (conidia) germinate to produce chains of elongated hyphal cells that grow across the surface of the plant. In order to obtain nutrients from the plant, the pathogen periodically produces a specialised structure called an appressorium that generates sufficient pressure to allow the fungus to insert a penetration peg through the cuticle and cell wall of a host epidermal cell. Once the cell wall has been breached, the pathogen invaginates the host cell membrane forming a multilobed structure called a 'haustorium' via which nutrients are obtained to allow the pathogen to reproduce and complete its life-cycle (Heintz and Blaich 1990, Glawe 2008).

The highly susceptible nature of $V$. vinifera to powdery mildew suggests that it lacks genetic mechanisms to protect itself from this pathogen. This is not surprising when one considers that $V$. vinifera is indigenous to Eurasia (This et al. 2006) whereas E. necator is endemic to North America and was only introduced into Europe in the 1840s, most probably on ornamental vines imported for use in European gardens. In evolutionary terms, therefore, $V$. vinifera has only been exposed to the $E$. necator pathogen for an extremely short period of time. In contrast, many grapevine species that are endemic to the USA display varying levels of resistance to powdery mildew (Pearson and Gadoury 1992) but these species lack the superior berry quality of the $V$. vinifera cultivars. Consequently, when attempts have been made to introduce powdery mildew resistance by conventional hybridisation between $V$. vinifera and North American Vitis sp., the resulting resistant hybrids have been generally unacceptable to growers and winemakers. The adoption of these 'French-American' hybrids has therefore been very limited throughout most viticultural regions of the world apart from eastern and mid-western USA (Pollefeys and Bousquet 2003). New molecular approaches are therefore required to introduce powdery mildew resistance into winegrape cultivars while maintaining wine quality.

\section{Current model of plant resistance to pathogens}

Bent and Mackey (2007) recently published an excellent review in which they proposed a revised four-part model to describe our current understanding of disease resistance mechanisms in plants (Figure 1). One of the key features of this model is that it helps describe the link, in both functional and evolutionary terms, between what we now understand are the two major mechanisms plants use in defence against pathogen attack.

The first of these is referred to as non-host resistance or basal immunity. This describes resistance which is effective across an entire plant species against all known isolates of a pathogen species. In cellular or molecular terms this encompasses both the preformed physical and chemical barriers that plant tissues have to pathogen invasion and the inducible immune response that is triggered by the recognition of a microbe-associated molecular pattern (MAMP) by an extracellular receptor-like kinase (RLK). MAMPs can be considered as defence elicitors that are evolutionarily stable, forming a core component of the microorganism that generally cannot be sacrificed or altered significantly without seriously impairing viability (Bent and Mackey 2007). In the case of powdery mildew, this is likely to include the chitin which makes up fungal cell walls (Bittel and Robatzek 2007). The recognition of a MAMP by the RLK triggers a basal immune response (also called MAMP-triggered immunity) which comprises a variety of defence responses including cytoskeleton rearrangements, callose deposition and the induction of antimicrobial compounds. Plant pathologists have long been aware of the existence of non-host resistance, but until recently much of the information we possessed was descriptive in nature because it was not amenable to classical genetic analysis. However, large-scale forward genetic screens on Arabidopsis have now identified a number of key genes designated PENETRATION1 (PEN1), PEN2 and PEN3 which play major roles in the basal immune response against powdery mildews (Collins et al. 2003, Lipka et al. 2005, Stein et al. 2006). Of particular interest is PEN1 which encodes a syntaxin involved in membrane fusion events at the plasma membrane. This protein has been shown to redistribute within cells, under powdery mildew attack, to focus beneath the point of attempted penetration (Assaad et al. 2004). Furthermore, PENl redistribution appears to be a unique response of plant cells to attempted penetration by powdery mildews and not by other fungal pathogens (Meyer et al. 2009). This suggests that PENl may have a role in trafficking of secretory vesicles to the plasma membrane containing cargo that is required for penetration resistance against powdery mildews.

In stage two of the model (Figure 1), certain species of the pathogen become 'adapted' to the host through the evolution of effector molecules that actively suppress the basal immune response and manipulate plant cell functions to facilitate infection. In the case of grapevines, $E$. necator appears to be the only powdery mildew species which has become adapted on this plant host. While there is a wealth of knowledge relating to the identity of the multiple effectors released by bacteria and oomycetes into plant cells during infection (Bent and Mackey 2007), to date there is only one report of two effectors identified from the cereal powdery mildew Blumeria graminis $f . s p$. hordei (Ridout et al. 2006). 


\section{Basal immunity}

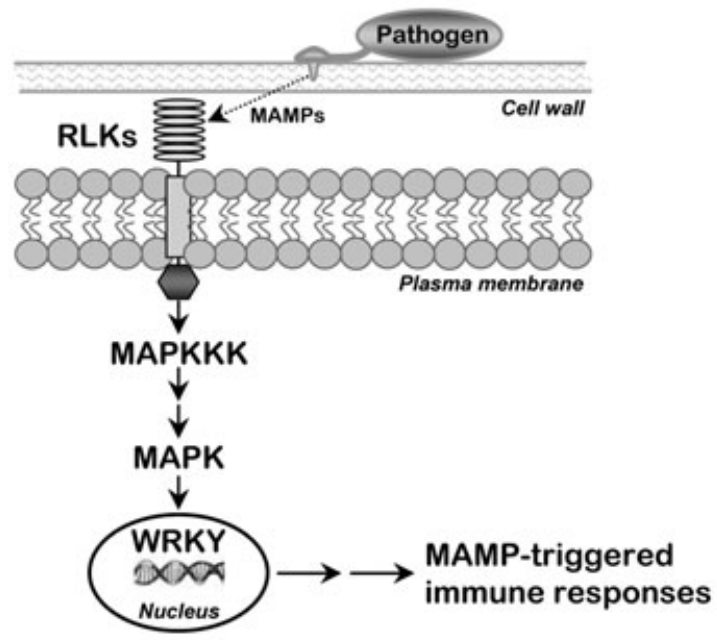

\section{Susceptibility}

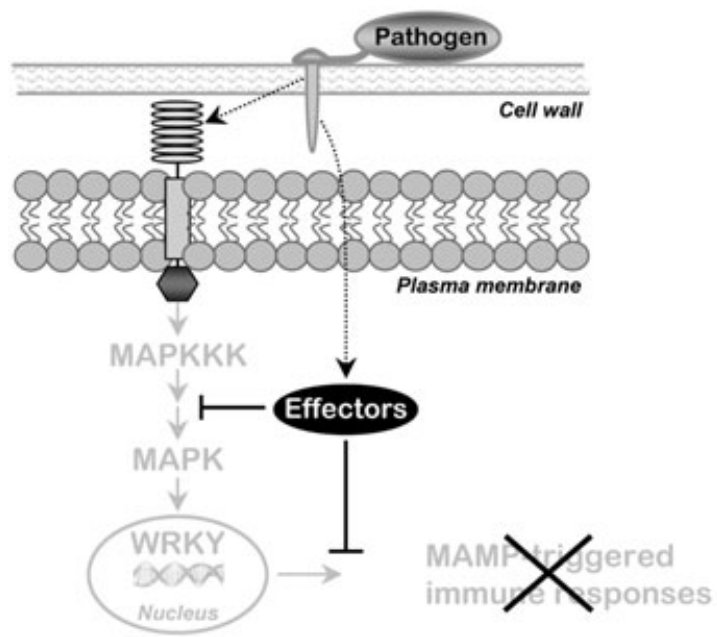

\section{3. $R$ gene resistance}

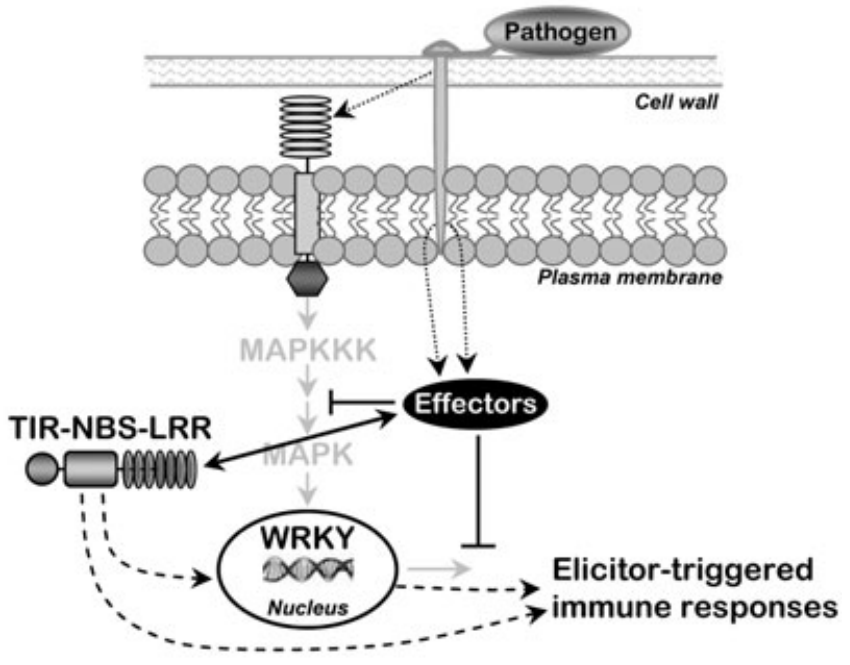

4. $R$ gene breakdown

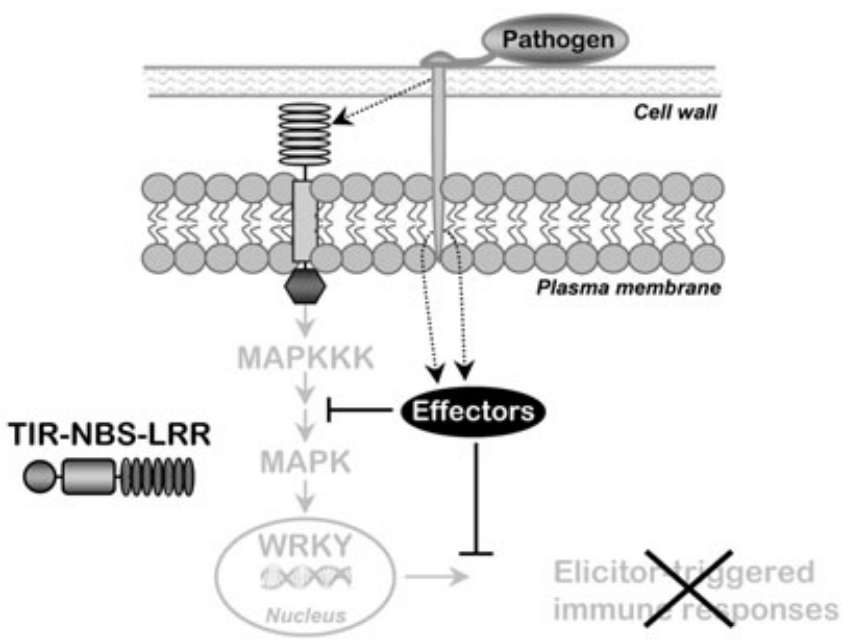

Figure 1. Model for the evolution of pathogen resistance in plants. This figure has been adapted from the model of Bent and Mackey (2007) using powdery mildew as the invading pathogen. Stage 1: Recognition of microbial-associated molecular patterns (MAMP; such as fungal chitin) by extracellular receptor-like kinases (RLKs) triggers basal immunity against non-adapted powdery mildew species, which includes signalling through MAP kinase cascades and transcriptional reprogramming mediated by plant WRKY transcription factors (proteins containing one or two highly conserved domains characterised by the heptapeptide WRYKGQK). Stage 2: Adapted powdery mildew species suppress basal immune responses possibly via release of effector molecules, allowing penetration of the cell wall. Stage 3: Plant resistance proteins ( $R$ gene products, such as TIR-NBS-LRR proteins: TIR, Toll/Interleukin-1 receptor domain; NBS, nucleotide-binding site domain; LRR, leucine-rich repeat domain) recognise effector activity and restore resistance through effector-triggered immune responses. Stage 4: Pathogen avoids $R$ gene-mediated defences by modifying or eliminating the effector(s) that trigger those defences.

Stage three of the model (Figure 1) describes the initial stages of the plant-pathogen 'arms race', whereby plant hosts which are susceptible to adapted pathogens, evolve specific resistance $(R)$ genes which enable the plant to detect the defence-suppressing effectors. This interaction initiates effector-triggered immune responses, thereby restoring resistance to the pathogen. Commonly, the result of defence activation involving $R$ genes is the localised death of the infected cells, termed a hypersensitive response, which prevents the pathogen from obtaining nutrients and completing its life cycle (Mur et al. 2008). The vast majority of $R$ genes encode proteins that contain leucine-rich repeats (LRRs), a central nucleotide-binding site (NBS) domain and a variable domain at the N-terminus, consisting of either a coiledcoil (CC) domain or a domain that has homology to the Toll/Interleukin-1 Receptor (TIR). With some exceptions, LRRs are mainly involved in recognition, the aminoterminal domain determines signalling specificity and the NBS domain appears to function as a molecular switch (Takken et al. 2006).

The final stage of the model describes a further evolution of the pathogen to avoid detection by the R protein by modifying or eliminating the effector(s) that triggers those defences (Figure 1). Clearly, any such changes in the pathogen effector must still be compatible with its role 

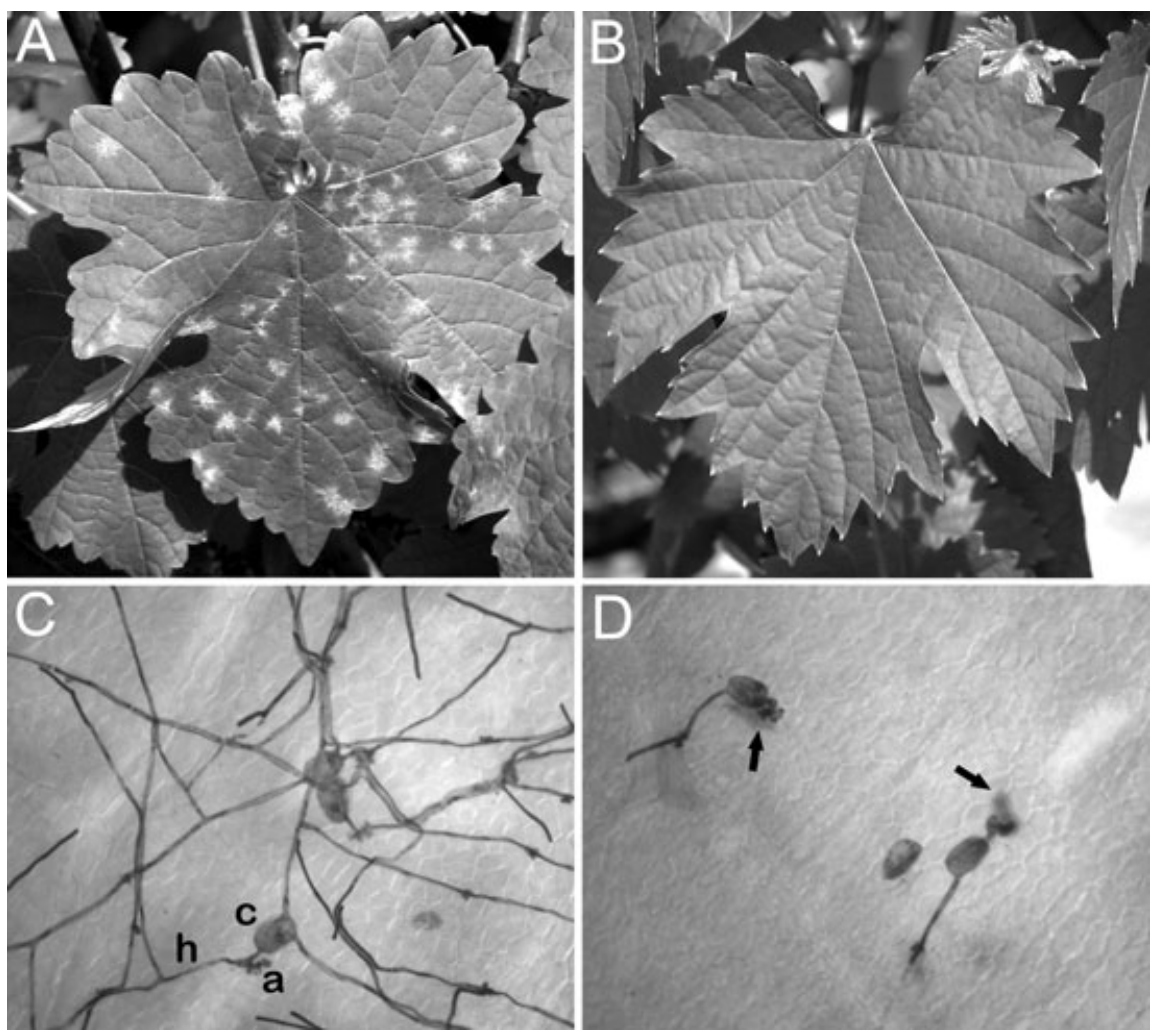

Figure 2. Powdery mildew development on leaves of susceptible ( $V$. vinifera $\mathrm{CV}$. Cabernet Sauvignon; panels A and $\mathrm{C}$ ) and resistant (Run1-containing BC4 progeny (see text for details); panels $B$ and D) grapevines. Panels A and $\mathrm{B}$ : glasshouse vines 2 weeks after inoculation with powdery mildew. Panels $\mathrm{C}$ and $D$ : detached leaves sampled $48 \mathrm{~h}$ post-inoculation and stained with Coomassie Blue to visualise fungal structures. Arrows indicate individual epidermal cells penetrated by powdery mildew that have undergone programmed cell death in leaves containing the Run1 locus. (c) conidium, (a) appressorium, (h) hypha.

as a virulence factor or the changes will not be maintained. This effectively returns the plant-pathogen interaction back to Stage 2, except that the pathogen has had to alter or lose an effector protein and resistance will only be re-established through the introduction of another $R$ gene that recognises the modified effector.

The major message from this model is that plants have evolved two overlapping defence pathways to detect and restrict the growth of invading pathogens. In this short review, we will focus on the different molecular strategies that we are currently employing in our laboratory to develop resistance to grapevine powdery mildew by manipulating these two defence pathways in susceptible grapevine cultivars.

\section{Identifying powdery mildew resistance genes in a wild North American grapevine}

\section{Genetic mapping and positional cloning}

The wild grape species Muscadinia rotundifolia, a native to the southeastern USA, is highly resistant to a number of pathogens known to affect cultivated grapevines, including powdery mildew, downy mildew, phylloxera and nematodes (Olmo 1986). M. rotundifolia is taxonomically separated from Euvitis species by anatomical and morphological characteristics (Planchon 1887) and a difference in chromosome number (Vitis $2 \mathrm{n}=38$, Muscadinia $2 \mathrm{n}=40$; Branas 1932). Not surprisingly, therefore, the first attempts to produce inter-specific crosses between $M$. rotundifolia and $V$. vinifera in the mid 1800s, were of only limited success. However, in 1919, L.R. Detjen, a grape breeder from North Carolina was successful in producing the first authentic hybrids between $V$. vinifera and $M$. rotundifolia using the $V$. vinifera cultivar Malaga as the female parent (Detjen 1919). One of the progeny, NC615, was used as the resistant parent in a series of pseudobackcrosses with $V$. vinifera cultivars that led to the identification of a single, dominant locus designated Runl (Resistance to Uncinula necator 1) that provided complete resistance to powdery mildew (Bouquet 1986, Pauquet et al. 2001). Analysis of the Runl-mediated resistance response indicates that it involves induction of programmed cell death, specifically within the penetrated epidermal cell, approximately 24-48 h following powdery mildew infection (Figure 2 ). Later studies with the same populations also identified a second resistance locus, designated Rpvl (for Resistance to Plasmopora viticola 1$)$ that provided partial resistance to downy mildew (Merdinoglu et al. 2003). Interestingly, Runl and Rpvl were found to co-segregate making it feasible to identify both resistance genes in a single map-based cloning effort.

Three back-cross populations Mtp3294 (BC4:VRH3082-1-42 × Cabernet Sauvignon), Mtp3328 (BC4:VRH3082-1-49 $\times$ Marselan) and Mtp3322 (BC5: VRH3176-21-11 × Cabernet Sauvignon) were used in genetic mapping studies to identify markers linked to the resistance loci (Pauquet et al. 2001, Barker et al. 2005). Using a bulked segregant analysis approach (Michelmore et al. 1991), a number of amplified fragment length polymorphism (AFLP) markers (Pauquet et al. 2001) and resistance gene analogue markers (RGAs; Donald et al. 2002) were identified that are linked to the Runl/Rpvl locus. RGA markers are based on the knowledge obtained from the cloning of a large number of plant disease resistance genes from plants, which indicate a high degree of structural conservation independent of the pathogen they confer resistance to. Highly conserved motifs within the 
NBS domain of R proteins (Takken et al. 2006) have been used to design degenerate primers capable of amplifying novel resistance gene analogues (RGAs) many of which have been found to map to resistance loci in a range of plant species (Aarts et al. 1998, Collins et al. 1998, Shen et al. 1998). Di Gaspero and Cipriani (2002) used a similar approach to clone a set of RGA sequences from the grape species Vitis amurensis and Vitis riparia which are known to show resistance to downy mildew and demonstrated that one of these RGA clones, rgVrip064, was linked to downy mildew resistance in segregating hybrid populations. In all a total of 14 AFLP, RGA and simple sequence repeat (SSR) markers were identified that showed linkage to the Runl/Rpvl resistance locus in the Mtp3294 and Mtp3328 populations (Barker et al. 2005). Based on the closest flanking SSR markers, VMC4f3.1 and VMC8g9, Runl/Rpvl is located on chromosome 12.

These genetic markers were used to screen a bacterial artificial chromosome (BAC) library constructed using genomic DNA of a single powdery mildew-resistant plant from the Mtp3294 mapping population (Barker et al. 2005). Assembly of the contigs between VMC4f3.1 and VMC8g9 indicated that the physical distance between these markers was much greater than initially suggested by the genetic mapping, necessitating the identification of more recombinants to further narrow the genomic region containing the Runl/Rpvl locus. To achieve this, approximately 3300 new progeny of the Mtp3294 and Mtp3322 populations were screened for recombination between VMC4f3.1 and VMC8g9 and the recombinants phenotyped for powdery and downy mildew resistance (C. Anderson, unpublished). This genetic analysis narrowed the Runl/Rpvl locus to a $\sim 1 \mathrm{Mbp}$ region of introgressed DNA. Sequencing of this region revealed the presence of a cluster of RGAs encoding TIR-NBS-LRR type resistance proteins. No other genes predicted to be involved in resistance against fungal pathogens were identified within this region.

In total, 11 RGAs have been identified at the Run I/ Rpvl locus (Figure 3). Seven of the RGAs encode full-

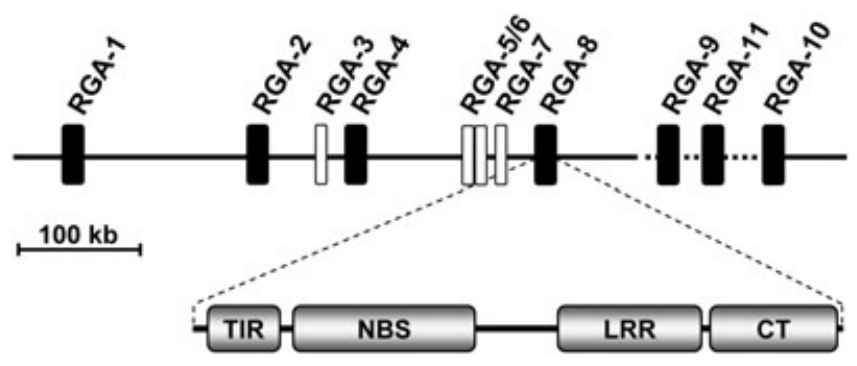

Figure 3. Arrangement and structure of resistance gene analogue (RGA) genes clustered at the Run locus. Black boxes represent full-length genes, open boxes are truncated genes. The dotted line represents regions of the genomic DNA for which overlapping clones could not be obtained from the Run1 BAC library. Translation of the RGA genes at the Run1 locus reveals the presence of four domains characteristic of TIR-NBS-LRR resistance genes: TIR, Toll/Interleukin-1 receptor domain; NBS, nucleotide-binding site domain; LRR, leucine-rich repeat domain; CT, C-terminal domain of undetermined function. length TIR-NBS-LRR resistance proteins; the remaining genes are truncated and lack either the TIR or the NBSLRR domain. Three of the RGAs (RGA-9, RGA-10 and RGA-11) were originally recovered as only partial length genomic clones associated with one of a number of 'gap' regions within the Runl BAC library for which overlapping BAC clones could not be found. Full-length genomic clones of these RGAs were obtained by genome walking techniques. The full-length RGAs are highly homologous apart from a variable number of LRR domains. Expression analysis indicates that all of the full-length RGA candidates are expressed in powdery mildew-resistant progeny, indicating that any one of these genes are candidates for conferring powdery mildew (and/or downy mildew) resistance. Significantly, the only other powdery mildew resistance genes which have been cloned to date are the Mla locus from barley (Zhou et al. 2001) and the Pm3 locus from wheat (Srichumpa et al. 2005) which also encode NBS-LRR type proteins but possess a CC domain at the N-terminus instead of a TIR domain.

It is interesting to note that having screened over 5000 backcross progeny in the course of this mapping project, we have not identified any plants which segregate differently for powdery mildew (Runl) or downy mildew $(R p v l)$ resistance. This suggests that either both mildew resistances are encoded by the same resistance gene or different members of the same resistance gene cluster. An NBS-LRR resistance protein that confers resistance to two completely different pathogens, i.e. the ascomycete fungus $E$. necator and the oomycete $P$. viticola, would be highly unusual, but not unique. The $M i$ gene from tomato, for example, confers resistance against both rootknot nematodes and potato aphids (Rossi et al. 1998).

\section{Functional testing of candidate resistance genes}

NBS-LRR resistance genes show 'restricted taxonomic functionality' which generally means they are only functional within species of the same taxonomic family (Michelmore 2003). Furthermore, biotrophic pathogens such as E. necator and P. viticola are specifically adapted to the grapevine host and cannot infect other plant species. This means that whereas most genes isolated from grapevine can be functionally evaluated in readily transformable model species such as Arabidopsis, tobacco or tomato, candidate grapevine powdery mildew resistance genes are unlikely to reveal function unless experiments are carried out in transgenic grapevines, the generation of which remains a time-consuming and inefficient process. Some progress has been made in the development of transient assay systems in grapevine (Santos-Rosa et al. 2008), but whether these systems are efficient enough to enable testing of resistance to biotrophic pathogens, such as powdery mildew, remains to be seen.

Another consideration when evaluating $R$ gene function in transgenic plants is the issue of promoter selection. The use of generic expression cassettes involving highly active constitutive promoters, such as 35S, may lead to autoactivity of the $\mathrm{R}$ proteins resulting in necrosis in the absence of the pathogen (Oldroyd and Staskawicz 1998, Tao et al. 2000, Bendahmane et al. 2002). This is thought 
to be either because of the titration of trans-acting repressors or an increase, beyond an activity threshold, of the steady-state level of $\mathrm{R}$ protein molecules, a proportion of which may exist in a spontaneously active state (Tao et al. 2000).

With these various considerations in mind, we are currently introducing individual genomic fragments $(\sim 12-14 \mathrm{~kb})$ encompassing the endogenous promoterRGA coding-endogenous terminator regions of each of the seven RGA candidates into powdery (and downy) mildew susceptible $V$. vinifera cultivars. This will enable us to determine not only which of the RGA candidates function as powdery and/or downy mildew resistance genes, but also test each of the candidate genes against different powdery and downy mildew isolates to determine if they are isolate-specific.

Considerations in the deployment of qualitative powdery mildew resistance genes in the vineyard

Durable resistance can be considered as resistance that remains effective when used in a large growing area, over a long period of time, under environments favourable to disease development (Leach et al. 2001). Perennial crops, like grapevines, provide particular challenges when considering the issue of durability. Most grapegrowers would have an expectation that individual vines would remain in the vineyard for at least 20 years and do not have the capacity to rapidly introduce new cultivars with different $R$ genes, as is the case for annual crops such as cereals, should existing $R$ genes fail.

Testing of Runl backcross lines against powdery mildew isolates in France and Australia has shown the Runl locus to be effective against all isolates tested to date. However, this may be because of the combined action of more than one $R$ gene located at the Runl locus. The $M$. rotundifolia cultivar G52 from which the Runl locus was originally obtained is thought to have arisen from a cross between the two $M$. rotundifolia cultivars Thomas and Hope (Detjen 1919). Even if both cultivars have contributed different $R$ genes to the Runl locus, it remains to be determined whether they would provide resistance to different powdery mildew isolates.

On the other hand, if it is determined that powdery mildew resistance at the Runl locus is only conferred by a single $R$ gene then this has important implications for the deployment of this resistance gene within the vineyard. To date, there are few examples of single dominant $R$ genes that have proven to be durable in the field. As outlined in Figure 1, interactions leading to host plant resistance involving these $R$ genes can be lost through modification or elimination of pathogen effector(s) that trigger the resistance response. Even the barley Rpgl gene which had provided effective control for almost 50 years in North America against stem rust caused by Puccinia graminis f. sp. tritici was finally compromised by the evolution of a new virulent pathotype (Steffenson 1992).

One approach which may improve the durability of resistance in the field, is to stack or pyramid multiple $R$ genes within a single cultivar such that, for a given pathogen, reproduction will be restricted even if individuals within the pathogen population are present that have lost, or modified, the interacting effector molecule for one of the $R$ genes. At least two other sources of resistance (or at least reduced susceptibility) to grapevine powdery mildew have been reported that appear to map to a different locus to Runl. A major QTL originating from an undetermined North American Vitis species has been mapped to chromosome 15 (Akkurt et al. 2006, Welter et al. 2007). Hoffmann et al. (2008) also recently reported on a dominant locus for powdery mildew resistance (designated REN1) from the central Asian $V$. vinifera cultivar Kishmish vatkana which maps to a 10 -cM region on chromosome 13. Interestingly, a family of NBS-LRR genes also maps to this same region raising the possibility that RENI is also an NBS-LRR gene. A number of groups have already commenced breeding programs to combine Run 1 resistance with these other powdery mildew resistance loci using marker assisted evaluation to follow the inheritance of both resistance loci (Eibach et al. 2007, Molnar et al. 2007)

The identification of dominant resistance to E. necator in $V$. vinifera $\mathrm{cv}$. Kishmish vatkana, would appear to be at odds somewhat, with the model of evolution of plant resistance described earlier (Figure 1), which proposes that $R$ gene mediated resistance is the result of a significant period of co-evolution between the host and an adapted pathogen. In addressing this conundrum, Hoffmann et al. (2008) proposed that wild $V$. vinifera populations in the Central Asia, unlike the clonally propagated cultivated grapevines in Europe, are undergoing sexual propagation, and may have evolved resistance since the arrival of E. necator from North America. An alternative explanation may be that $E$. necator has actually been in Central Asia for a much longer period than first thought. The existence of a large number of wild Chinese Vitis species which also show significant resistance to E. necator (Wan et al. 2007) also lends support for this hypothesis, although the actual mechanism of resistance in these Chinese species has not been reported.

\section{An alternative strategy to powdery mildew resistance: re-establishing basal immunity against E. necator}

According to the model outlined in Figure 1, powdery mildew species which have become adapted on particular plant hosts, are able to suppress basal immune responses to allow penetration, whereas non-adapted species are unable to do this and fail to enter the epidermal cell. For example, in the case of $V$. vinifera cv. Cabernet Sauvignon, inoculation with the adapted powdery mildew species $E$. necator results in rates of successful penetration (as determined by the presence of haustoria in epidermal cells) of over $90 \%$ within $48 \mathrm{~h}$, whereas inoculation with the non-adapted cucurbit powdery mildew species E. cichoracearum under the same conditions, results in rates of successful penetration of $<15 \%$ (A. Feechan, unpublished). It is still not understood how adapted powdery mildew species are able to suppress basal immunity to enable such high rates of successful penetration on host species. However, evidence obtained from studies on naturally 
occurring mutants, in which the basal immune response against a previously adapted powdery mildew species has been re-established, may offer some insights.

\section{A role for $M L O$ in suppressing basal immunity against powdery mildew?}

German expeditions to Ethiopia in 1937-1938 collected seed samples of barley landraces which were found to exhibit broad-spectrum resistance against all isolates of barley powdery mildew (Blumeria graminis f. sp. hordei; Peterhänsel and Lahaye 2005). However, what was even more surprising was that this spontaneously occurring resistance allele, designated mlo (powdery mildew resistance gene $\mathrm{o}$ ), was inherited in a recessive manner. The wild type $\overline{H v M L O}$ gene was cloned from barley in 1997 and found to encode a plant-specific 7 transmembrane domain protein that resides in the plasma membrane (Büschges et al. 1997, Devoto et al. 1999). Since then, a naturally occurring allele (ol-2), derived from a Central American tomato (Solanum lycospersicum) accession, that confers broad-spectrum and recessively inherited resistance to tomato powdery mildew (Oidium neolycopersici), has been demonstrated to be due to loss of function of the SlMLO1 gene (Bai et al. 2008). Finally, a homozygous T-DNA insertion line in the Arabidopsis AtMLO2 gene, has been shown to have significantly reduced susceptibility to Erysiphe orontii (Consonni et al. 2006), with mutation of two other closely related genes, AtMLO6 and AtMLO12 also required to achieve complete powdery mildew resistance.

One of the characteristics of the resistance mediated by $m l o$ is the failure of the adapted powdery mildew species to successfully penetrate epidermal cells, which is reminiscent of the phenotype observed following inoculation with a non-adapted powdery mildew species. It has also been shown that mlo resistance in barley is dependent on the presence of ROR2 (Collins et al. 2003), an orthologue of the Arabidopsis PENI gene shown to be involved in basal immunity against non-adapted powdery mildews (see previous section). Furthermore, studies have revealed that, like the PEN1 and ROR2 proteins, wild-type MLO becomes polarised at the site of attempted powdery mildew ingress (Bhat et al. 2005). The shared histological and phytopathological characteristics, together with the conserved requirement for PEN1/ROR2 in both basal immunity against non-adapted powdery mildew species, and MLO-mediated resistance against adapted powdery mildew species, strongly suggests a common mechanism of resistance (Humphry et al. 2006). In other words, mutation of the wild-type $M L O$ gene effectively re-establishes basal immunity against the adapted powdery mildew species.

The mechanism by which wild-type MLO protein might interfere with or suppress PENl-mediated basal immunity is yet to be determined. Meyer et al. (2009) have postulated that the co-localisation of MLO and PEN1/ROR2 within the plasma membrane, beneath the site of attempted penetration, might directly interfere or antagonise the PEN1/ROR2-mediated processes required for basal immunity against powdery mildew. If this were the case, it also implies that adapted powdery mildew species are able to hijack MLO to suppress basal immunity whereas the non-adapted species cannot.

\section{Functional characterisation of the MLO gene family in grapevine}

Independent of the mechanism involved, the work described previously with barley, tomato and Arabidopsis clearly demonstrates that it is feasible to re-establish basal immunity against an adapted powdery mildew species by targeted mutation or silencing of host $M L O$ gene(s). However, the challenge is to determine which MLO gene(s) to target. For example, A. thaliana contains 15 MLO genes, but only three (AtMLO2, AtMLO6 and AtMLO12) appear to have a role in powdery mildew susceptibility (Consonni et al. 2006). Analysis of the recently released $V$. vinifera genome indicates there may be as many as $17 V v M L O$ genes in grapevine (Feechan et al. 2008, Winterhagen et al. 2008).

As a first step, we undertook phylogenetic analysis of the translated products of the $V v M L O$ gene family together with other known plant MLO sequences. Of the $17 V v M L O$ genes analysed, six (VvMLO3, VvMLO4, VvMLO6, VvMLO9, VvMLO13 and VvMLO17) clustered within the same clade as the Arabidopsis and tomato MLO genes that have been demonstrated to be required for powdery mildew susceptibility (Feechan et al. 2008). Of these six genes, three (VvMLO3,VvMLO4 and VvMLO17) were found to be induced significantly in grape leaves within 8 h of $E$. necator inoculation, which coincided with the commencement of fungal penetration (Figure 4). Transcript abundance of VvMLO4 and VvMLO17 then decreased, while $V v M L O 3$ expression remained relatively constant during the period $8-20 \mathrm{~h}$ post-inoculation. $V v M L O 9$ was also found to exhibit increased transcript levels following $E$. necator inoculation, but the timing was delayed relative to the other powdery mildew-induced $V v M L O$ genes, whereas none of the other eight $V v M L O$ genes examined were induced greater than twofold in response to powdery mildew inoculation. The transient transcriptional response of $V v M L O 17, V v M L O 3$ and $V v M L O 4$ to E. necator penetration is consistent with that previously reported for $H v M L O$ in response to $B$. graminis infection (Piffanelli et al. 2002).

The similarities in both sequence homology and transcriptional regulation suggests that VvMLO3, VvMLO4 and $V v M L O 17$, may have functionally similar roles to those $M L O$ genes from barley, Arabidopsis and tomato (described previously) which have been shown to modulate powdery mildew susceptibility. It may also indicate some level of functional redundancy between these three $V v M L O$ genes as is the case in Arabidopsis. Experiments are now underway in our laboratory to try and establish if selective silencing of any of these $V v M L O$ genes individually, or in combination, has any impact on powdery mildew susceptibility. The outcome of these experiments will have important implications for any future strategies to engineer powdery mildew resistance based on $M L O$ suppression. If resistance in grapevine can be achieved through the silencing of a single $V v M L O$ gene, as in 


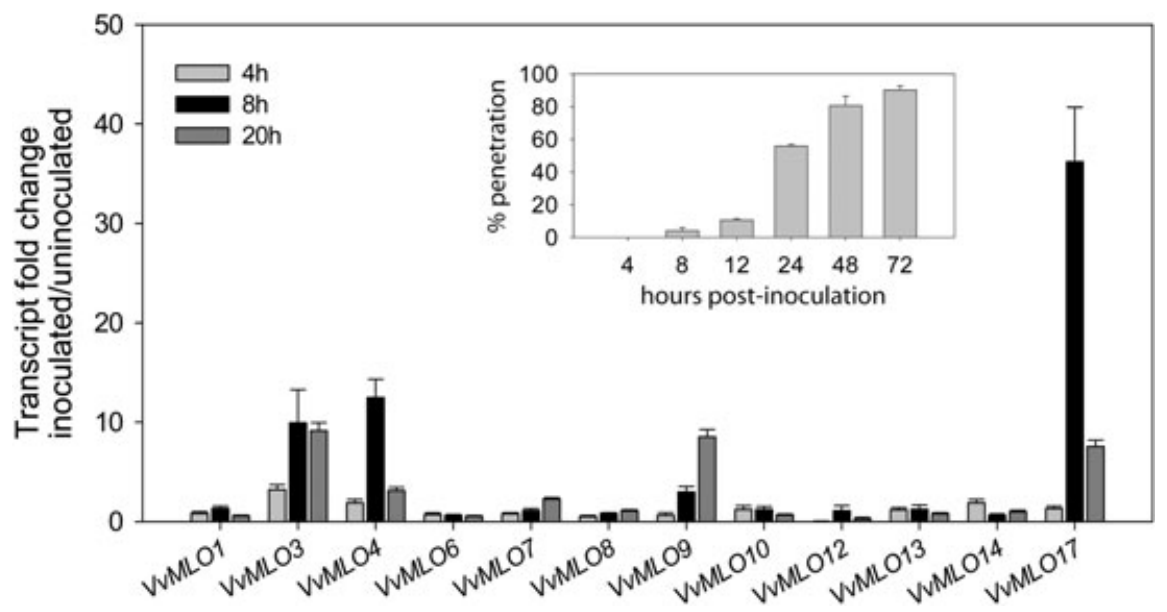

Figure 4. Transcriptional response of grapevine VVMLO genes to powdery mildew infection. Detached V. vinifera cv. Cabernet Sauvignon leaves were heavily inoculated with $E$. necator spores and sampled at 4, 8, 12, 24, 48 and 72 for scoring penetration efficiency and 4, 8 and $20 \mathrm{~h}$ for gene expression analysis. Inset: The incidence of epidermal host cell penetration by individual germinated conidia, scored via the presence of a haustorium. Each data point represents the scoring of a minimum of 100 germinated conidia with two replicates. The mean is shown and error bars are standard errors. Main graph: Quantitative RT-PCR analysis of VVMLO gene expression. Control (un-inoculated) detached leaves were incubated and sampled as for the inoculated leaves. Transcript levels of individual VVMLO genes were normalised against the transcript levels of EF1 in each cDNA sample. Results are plotted as a mean ratio of the normalised transcript level of each VVMLO gene in inoculated leaves versus the normalised transcript level of each VVMLO gene in control leaves. Means are totals calculated from triplicate technical qRT-PCR measurements within three biological replicates and the data shown are representative of the results obtained in the three independent experiments. Error bars are standard errors. This figure has been modified from Functional Plant Biology 35(12) 1255-1266, http://www.publish.csiro.au/paper/FP08173.htm.

tomato (Bai et al. 2008), it would then be feasible to initiate a search for naturally occurring mutant alleles within $V$. vinifera germplasm collections that could be used in marker-assisted selection to generate progeny that are homozygous recessive at this locus. If, on the other hand complete powdery mildew resistance in grapevine is only achieved through the silencing of more than one $V v M L O$ gene, then this is realistically only amenable to transgenic approaches using constructs designed to simultaneously silence multiple $V v M L O$ genes. Such an approach has already been shown to be feasible in Arabidopsis (Consonni et al. 2006).

\section{Ontogenic resistance: the return of basal immunity?}

Ontogenic or age-related resistance describes an increase in the ability of whole plants or plant tissues to resist pathogen infection as they age or mature. It is exhibited towards viral, bacterial, oomycete and fungal pathogens (Panter and Jones 2002, Develey-Rivière and Galiana 2007). Grapevines show ontogenic resistance to several fungal pathogens including powdery mildew (Gadoury et al. 2003), downy mildew (Kennelly et al. 2005), and black rot (Hoffman et al. 2002).

Delp (1954) originally reported field and laboratory observations that immature grapes were susceptible to infection, but that no new infections occurred once the concentration of soluble solids exceeded $8^{\circ}$ Brix. Chellemi and Marois (1992) also reported that grapes became resistant to powdery mildew infection above $7^{\circ}$ Brix. As the apparent decrease in powdery mildew susceptibility of grape berries post-veraison, coincided with a marked increase in the accumulation of pathogenesis-related proteins, it was postulated that these proteins may have a role in ontogenic resistance (Robinson et al. 1997, Tattersall et al. 1997). However, subsequent studies showed that ontogenic resistance to powdery mildew is actually expressed at a much earlier stage of berry development, with berries of several cultivars of $V$. vinifera and $V$. labruscana immune to infection within 3-5 weeks after bloom (Ficke et al. 2003, Gadoury et al. 2003).

Although the mechanism of ontogenic resistance in grape berries is not fully understood, it appears to operate at the level of the epidermal cell wall resulting in an inhibition of penetration (Ficke et al. 2003). This increased penetration resistance could not be correlated with cuticular or cell wall thickness or the production of antimicrobial phenolics, leading Ficke et al. (2004) to postulate that ontogenic resistance in grape berries is mediated by the development of either (i) a physical or biochemical barrier near the cuticle surface or (ii) an inducible system for the rapid synthesis of an antifungal compound.

It is interesting to note that the increased penetration resistance observed in developing grape berries against the adapted powdery mildew species $E$. necator, is comparable to the observed response of grape leaves to attempted penetration by a non-adapted powdery mildew species such as E. cichoracearum (see previous discussion). This raises the question as to whether the development of ontogenic resistance reflects a decrease in the capacity of $E$. necator to continue to suppress basal immunity. We are currently investigating components of the basal immunity pathway in grapevine in order to test this hypothesis. 
If we could determine the molecular/genetic basis of ontogenic resistance to powdery mildew in grape berries, it may be possible to use this information to manipulate broad-spectrum, durable resistance to powdery mildew in other highly susceptible grapevine tissues. Recent work by Gee et al. (2008) has identified a strategy via which the determination of the mechanism of ontogenic resistance might be achieved. They screened a diverse collection of Vitis species and interspecific hybrids for the development of ontogenic resistance in berries under field conditions. Of the 79 genotypes investigated, 50 showed little or no sign of disease when inoculated, irrespective of the stage of berry development at inoculation, 24 exhibited a significant gain of resistance as berries aged and four genotypes exhibited no statistically significant pattern. However, more importantly, one genotype ( $V$. rupestris 'R-65-44') remained susceptible past the onset of ripening, over 1 month later than reported previously for $V$. vinifera. The discovery of significant genotypic variation in ontogenic resistance now offers the possibility of undertaking genetic studies to investigate the inheritance and molecular basis of this powdery mildew resistance character.

\section{Final considerations}

We are employing a number of molecular approaches in our quest to try and introduce significant and durable resistance to powdery mildew into $V$. vinifera. Of the three approaches described, integration of the Runl locus from $M$. rotundifolia into $V$. vinifera has clear potential for generating new powdery mildew-resistant winegrape cultivars. Our research is focussed on identifying which of the individual resistance gene candidates, located at the Runl locus, contributes to powdery (and downy) mildew resistance. Functional demonstration of mildew resistance mediated by a single $R$ gene in a $V$. vinifera genetic background, would open up the possibility of introducing this gene into existing elite cultivars with minimal impacts on wine quality. However, as work with other pathosystems has shown, the use of single dominant resistance genes is not without potential problems in terms of durability in the field. It will be important to obtain information regarding the existence and distribution of any E. necator isolates, most probably within North America, which can overcome Runl-mediated resistance. Where possible, new winegrape cultivars should also contain resistance genes from multiple sources, to reduce the risk of generating new compatible isolates. However, this clearly adds another level of complexity in terms of plant breeding or genetic transformation.

While as yet unproven in grapevine, the MLO mutation approach offers some advantages over resistance based on Runl, because of its potential to deliver broadspectrum, durable resistance to powdery mildew. If a member of the $V v M L O$ gene family is demonstrated to act as a powdery mildew susceptibility gene in grapevine, the most likely mode of delivery is via genetic modification of existing cultivars. However, powdery mildew resistance obtained through $M L O$ mutation may not come without a price. Barley and Arabidopsis mlo mutants have been found to show enhanced susceptibility to some hemi- biotrophic and necrotrophic pathogens (Jarosch et al. 1999, Kumar et al. 2001, Consonni et al. 2006). As grapevines are exposed to a broad range of pathogens within the different regions of the world in which they are cultivated, deployment of grapevine MLO mutants, would need to be preceded by field trials designed to evaluate the impact of this mutation on susceptibility to pathogens other than powdery mildew. It also remains to be seen if silencing of $V v M L O$ gene(s) will have any pleiotropic effects on grapevine growth and development. MLO mutants of barley and Arabidopsis display a range of developmentally regulated pleiotropic effects, including the spontaneous deposition of callose-containing cell wall appositions and the premature onset of leaf senescence (Peterhänsel et al. 1997, Piffanelli et al. 2002, Consonni et al. 2006). However, similar developmentally regulated pleiotropic effects were not observed on powdery mildew resistant tomato mlo mutants (Bai et al. 2008). The impaired leaf physiology of barley mlo plants results in some reduced grain yield compared with wild-type plants and this initially hampered the use this germplasm despite its broad-spectrum resistance to powdery mildew. The possible appearance of similar pleiotropic effects on grapevine leaves is unlikely to cause significant issues for grapegrowers because photosynthetic capacity is not normally a limiting factor in grape production. Indeed, it is likely that most growers would even tolerate some loss in maximum cropping capacity in exchange for durable resistance to powdery mildew. However, it will be important to confirm that the mutation of specific $V v M L O$ gene(s) in grapevine does not lead to any deleterious effects on berry yield or quality.

An over-arching issue across all of these considerations is the continuing uncertainty regarding the adoption of transgenic vines in the major wine-making countries and whether this could be used by some countries as a trade barrier. In comparison with classical breeding techniques, genetic transformation offers the capacity to move resistance genes between different grapevine species that cannot be readily hybridised by traditional breeding techniques, or selectively silence host genes which pre-dispose plants to infection. It also retains the unique genetic make-up of our elite wine cultivars, which may be lost through the use of classical breeding techniques because of the high level of heterozygosity of the grape genome. Indeed, despite the best efforts of grapevine breeders, not one new powdery mildew-resistant cultivar has been developed, since the invasion of $E$. necator into Europe in the 1840s, that has been adopted to any significant extent by growers. However, with the development of genetic markers linked to both qualitative and quantitative disease resistance loci and the employment of marker assisted selection strategies, the breeding of new disease resistant winegrape cultivars may be about to undergo a renaissance.

\section{Acknowledgements}

This work was funded by the Grape and Wine Research Development Corporation of Australia. We thank Nicole Kempster, Karina Swann and Pat Corena for excellent 
technical assistance. This paper is dedicated to the memory of Dr Alain Bouquet who passed away suddenly on 11 th May 2009. Alain was an enthusiastic, committed and extremely generous scientist whose vision and creativity has paved the way for many of the breakthroughs in grapevine genetics that are now being achieved by grape researchers throughout the world.

\section{References}

Aarts, M.G.M., te Lintel Hekkert, B., Holub, E.B., Beynon, J.L., Stiekema, W.J. and Pereira, A. (1998) Identification of r-gene homologous DNA fragments genetically linked to disease resistance loci in Arabidopsis thaliana. Molecular Plant Microbe Interactactions 11, 251-258.

Akkurt, M., Welter, L., Maul, E., Töpfer, R. and Zyprian, E. (2006) Development of SCAR markers linked to powdery mildew (Uncinula necator) resistance in grapevine (Vitis vinifera L. and Vitis sp). Molecular Breeding 19, 103-111.

Assaad, F.F., Qiu, J-L., Youngs, H., Ehrhardt, D., Zimmerli, L., Kalde, M., Wanner, G., Peck, S.C., Edwards, H., Ramonell, K., Somerville, C.R. and Thordal-Christensen, H. (2004) The PENl syntaxin defines a novel cellular compartment upon fungal attack and is required for the timely assembly of papillae. Molecular Biology of the Cell 15, 5118-5129.

Bai, Y., Pavan, S., Zheng, Z., Zappel, N.F., Reinstädler, A., Lotti, C., De Giovanni, C., Ricciardi, L., Lindhout, P., Visser, R., Theres, K. and Panstruga, R. (2008) Naturally occurring broad-spectrum powdery mildew resistance in a Central American tomato accession is caused by loss of Mlo function. Molecular Plant Microbe Interactions 21, 30-39.

Barker, C.L., Donald, T., Pauquet, J., Ratnaparkhe, M.B., Bouquet, A., Adam-Blondon, A-F., Thomas, M.R. and Dry, I. (2005) Genetic and physical mapping of the grapevine powdery mildew resistance gene, Runl, using a bacterial artificial chromosome library. Theoretical and Applied Genetics 111, 370-377.

Baudoin, A., Olaya, G., Delmotte, F., Colcol, J.F. and Sierotzki, H (2008) QoI resistance of Plasmopara viticola and Erysiphe necator in the mid-Atlantic United States. Online. Plant Health Progress, Doi: 10.1094/PHP-2008-0211-02-RS.

Bendahmane, A., Farnham, G., Moffett, P. and Baulcombe, D.C. (2002) Constitutive gain-of-function mutants in a nucleotide binding site leucine rich repeat protein encoded at the $R x$ locus of potato. The Plant Journal 32, 195-204.

Bent, A.F. and Mackey, D. (2007) Elicitors, effectors, and R genes: the new paradigm and a lifetime supply of questions. Annual Review of Phytopathology 45, 399-436.

Bhat, R.A., Miklis, M., Schmelzer, E., Schulze-Lefert, P. and Panstruga, R. (2005) Recruitment and interaction dynamics of plant penetration resistance components in a plasma membrane microdomain. Proceedings of National Academy of Sciences U.S.A. 102, 3135-3140.

Bittel, P. and Robatzek, S. (2007) Microbe-associated molecular patterns (MAMPs) probe plant immunity. Current Opinion in Plant Biology 10, 335-341.

Bouquet, A. (1986) Introduction dans l'espèce Vitis vinifera L. d'un caractère de résistance à l'oidium (Uncinula necator Schw. Burr.) issu de l'espèce Muscadinia rotundifolia (Michx.) Small. Vignevini 12 (Suppl), 141-146.

Branas, M.M. (1932) Sur la caryologie des Ampélidées. C R Acad Sci Paris 194, 121-123.

Büschges, R., Hollricher, K., Panstruga, R., Simons, G., Wolter, M., Frijters, A., van Daelen, R., van der Lee, T., Diergaarde, P., Groenendijk, J., Topsch, S., Vos, P., Salamini, F. and SchulzeLefert, P. (1997) The barley Mlo gene: a novel control element of plant pathogen resistance. Cell 88, 695-705.

Calonnec, A., Cartolaro, P., Poupot, C., Dubourdieu, D. and Darriet, P. (2004) Effects of Uncinula necator on the yield and quality of grapes (Vitis vinifera) and wine. Plant Pathology 53, $434-445$.
Chellemi, D.O. and Marois, J.J. (1992) Influence of leaf removal, fungicide applications, and fruit maturity on incidence and severity of grape powdery mildew. American Journal of Enology and Viticulture 43, 53-57.

Collins, N.C., Thordal-Christensen, H., Lipka, V., Bau, S., Kombrink, E., Qiu, J.L., Hückelhoven, R., Stein, M., Freialdenhoven, A., Somerville, S.C. and Schulze-Lefert, P. (2003) SNAREprotein-mediated disease resistance at the plant cell wall. Nature 425, 973-977.

Collins, N.C., Webb, C.A., Seah, S., Ellis, J.G., Hulbert, S.H. and Pryor, A. (1998) The isolation and mapping of disease resistance gene analogues in maize. Molecular Plant Microbe Interactions 11, 968-978.

Consonni, C., Humphry, M.E., Hartmann, H.A., Livaja, M., Durner, J., Westphal, L., Vogel, J., Lipka, V., Kemmerling, B., Schulze-Lefert, P., Somerville, S.C. and Panstruga, R. (2006) Conserved requirement for a plant host cell protein in powdery mildew pathogenesis. Nature Genetics 38, 716-720.

Delp, C.J. (1954) Effect of temperature and humidity on the grape powdery mildew fungus. Phytopathology 44, 615-626.

Detjen, L.R. (1919) The limits in hybridisation of Vitis rotundifolia with related species and genera. North Carolina Agricultural Experiment Station Bulletin 17, 409-429.

Develey-Rivière, M-P. and Galiana, E. (2007) Resistance to pathogens and host developmental stage: a multifaceted relationship within the plant kingdom. New Phytologist 175, 405-416.

Devoto, A., Piffanelli, P., Nilsson, I., Wallin, E., Panstruga, R., von Heijne, G. and Schulze-Lefert, P. (1999) Topology, subcellular localization, and sequence diversity of the MLO family in plants. Journal of Biological Chemistry 274, 34993-35004.

Di Gaspero, G. and Cipriani, G. (2002) Resistance gene analogs are candidate markers for disease- resistance genes in grape (Vitis spp.). Theoretical and Applied Genetics 106, 163-172.

Donald, T.M., Pellerone, F., Adam-Blondon, A-F., Bouquet, A., Thomas, M.R. and Dry, I. (2002) Identification of resistance gene analogs linked to a powdery mildew resistance locus in grapevine. Theoretical and Applied Genetics 104, 610-618.

Eibach, R., Zyprian, E., Welter, L. and Topfer, R. (2007) The use of molecular markers for pyramiding resistance genes in grapevine breeding. Vitis 46, 120-124.

Erickson, E.O. and Wilcox, W.F. (1997) Distributions of sensitivities to three sterol demethylation inhibitor fungicides among populations of Uncinula necator sensitive and resistant to triadimefon. Phytopathology 87, 784-791.

Feechan, A., Jermakow, A.M., Torregrosa, L., Panstruga, R. and Dry, I.B. (2008) Identification of grapevine MLO gene candidates involved in susceptibility to powdery mildew. Functional Plant Biology 35, 1255-1266.

Ficke, A., Gadoury, D.M., Godfrey, D. and Dry, I.B. (2004) Host barriers and responses to Uncinula necator in developing grape berries. Phytopathology 94, 438-445.

Ficke, A., Gadoury, D.M., Seem, R.C. and Dry, I.B. (2003) Effects of ontogenic resistance upon establishment and growth of Uncinula necator on grape berries. Phytopathology 93, 556563.

Gadoury, D.M., Seem, R.C., Ficke, A. and Wilcox, W.F (2003) Ontogenic resistance to powdery mildew in grape berries. Phytopathology 93, 547-555.

Gadoury, D.M., Seem, R.C., Pearson, R.C., Wilcox, W.F. and Dunst, R.M. (2001) Effects of powdery mildew on vine growth, yield, and quality of Concord grapes. Plant Disease 85, 137140.

Gadoury, D.M., Seem, R.C., Wilcox, W.F., Henick-Kling, T., Conterno, L., Day, A. and Ficke, A. (2007) Effects of diffuse colonization of grape berries by Uncinula necator on bunch rots, berry microflora, and juice and wine quality. Phytopathology 97, 13561365.

Gee, C.T., Gadoury, D.M. and Cadle-Davidson, L. (2008) Ontogenic resistance to Uncinula necator varies by genotype and tissue type in a diverse collection of Vitis spp. Plant Disease 92, 10671073. 
Glawe, D.A. (2008) The Powdery Mildews: a review of the world's most familiar (yet poorly known) plant pathogens. Annual Review of Phytopathology 46, 27-51.

Heintz, C. and Blaich, R. (1990) Ultrastructural and histochemical studies on interactions between Vitis vinifera L. and Uncinula necator (Schw.) Burr. New Phytologist 115, 107-117.

Hoffman, L.E., Wilcox, W.F., Gadoury, D.M. and Seem, R.C. (2002) Influence of grape berry age on susceptibility to Guignardia bidwelli and its incubation period length. Phytopathology 92, 1068-1076.

Hoffmann, S., Di Gaspero, G., Kovács, L., Howard, S., Kiss, E., Galbács, Z., Testolin, R. and Kozma, P. (2008) Resistance to Erysiphe necator in the grapevine 'Kishmish vatkana' is controlled by a single locus through restriction of hyphal growth. Theoretical and Applied Genetics 116, 427-438.

Humphry, M., Consonni, C. and Panstruga, R. (2006) mlo-Based powdery mildew immunity: silver bullet or simply non-host resistance? Molecular Plant Pathology 7, 605-610.

Jarosch, B., Kogel, K.-H. and Schaffrath, U. (1999) The ambivalence of the barley Mlo locus: mutations conferring resistance against powdery mildew (Blumeria graminis f. sp. hordei) enhance susceptibility to the rice blast fungus Magnaporthe grisea. Molecular Plant Microbe Interactions 12, 508-514.

Kennelly, M.M., Gadoury, D.M., Wilcox, W.F., Magarey, P.A. and Seem, R.C. (2005) Seasonal development of ontogenic resistance to downy mildew in grape berries and rachises. Phytopathology 95, 1445-1452.

Kumar, J., Hückelhoven, R., Beckhove, U., Nagarajan, S. and Kogel, K.-H. (2001) A compromised Mlo pathway affects the response of barley to the necrotrophic fungus Bipolaris sorokiniana (Teleomorph: Cochliobolus sativus) and its toxins. Phytopathology 91, 127-133.

Leach, J.E., Cruz, V., Casiana, M., Bai, J. and Leung, H. (2001) Pathogen fitness penalty as a predictor of durability of disease resistance genes. Annual Review of Phytopathology 39, 187-224. Lipka, V., Dittgen, J., Bednarek, P., Bhat, R., Wiermer, M., Stein, M., Landtag, J., Brandt, W., Rosahl, S., Scheel, D., Llorente, F., Molina, A., Parker, J., Somerville, S. and Schulze-Lefert, P. (2005) Pre- and postinvasion defences both contribute to nonhost resistance in Arabidopsis. Science 310, 1180-1183.

Merdinoglu, D., Wiedeman-Merdinoglu, S., Coste, P., Dumas, V., Haetty, S., Butterlin, G. and Greif, C. (2003) Genetic analysis of downy mildew resistance derived from Muscadinia rotundifolia. Acta Horticulturae 603, 451-456.

Meyer, D., Pajonk, S., Micali, C., O'Connell, R. and SchulzeLefert, P. (2009) Extracellular transport and integration of plant secretory proteins into pathogen-induced cell wall compartments. The Plant Journal 57, 986-999.

Michelmore, R.W. (2003) The impact zone: genomics and breeding for durable resistance. Current Opinion in Plant Biology 6, 397404.

Michelmore, R.W., Paran, I. and Kesseli, R.V. (1991) Identification of markers linked to disease-resistance genes by Bulked Segregant Analysis: a rapid method to detect markers in specific genomic regions by using segregating populations. Proceedings of National Academy of Sciences U.S.A. 88, 9828-9832.

Molnar, S., Galbacs, Z., Halasz, G., Hoffmann, S., Kiss, E., Kozma, P., Veres, A., Galli, Z., Szoke, A. and Heszky, L. (2007) Marker assisted selection (MAS) for powdery mildew resistance in a grapevine hybrid family. Vitis 46, 212-213.

Mur, L.A.J., Kenton, P., Lloyd, A.J., Ougham, H. and Prats, E. (2008) The hypersensitive response; the centenary is upon us but how much do we know? Journal of Experimental Botany 59, 501-520.

Oldroyd, G.E.D. and Staskawicz, B.J. (1998) Genetically engineered broad-spectrum disease resistance in tomato. Proceedings of National Academy of Sciences U.S.A. 95, 10300-10305.

Olmo, H.P. (1986) The potential role of (vinifera $x$ rotundifolia) hybrids in grape variety improvement. Experientia 42, 921-926. Panter, S.N. and Jones, D.A. (2002) Age-related resistance to plant pathogens. Advances in Botanical Research 38, 251-280.
Pauquet, J., Bouquet, A., This, P. and Adam-Blondon, A-F. (2001) Establishment of a local map of AFLP markers around the powdery mildew resistance gene Runl in grapevine and assessment of their usefulness for marker assisted selection. Theoretical and Applied Genetics 103, 1201-1210.

Pearson, R.C. and Gadoury, D.M. (1992) Grape powdery mildew. In: Plant diseases of international importance, Vol. III, Diseases of fruit crops. Eds. J. Kumar, H.S. Chaube, U.S. Singh and A.N. Mukhopadhyay (Prentice Hall: Upper Saddle River, NJ) p. 456.

Pesticides Safety Directorate (2008) Pesticides Safety Directorate website. (UK Government) http://www.pesticides.gov. uk/uploadedfiles/Web_Assets/PSD/Impact_report_final_(May_ 2008).pdf [accessed 29/10/2009].

Peterhänsel, C. and Lahaye, T. (2005) Be fruitful and multiply: gene amplification inducing pathogen resistance. Trends in Plant Science 10, 257-260.

Peterhänsel, C., Freialdenhoven, A., Kurth, J., Kolsch, R. and Schulze-Lefert, P. (1997) Interaction analyses of genes required for resistance responses to powdery mildew in barley reveal distinct pathways leading to leaf cell death. The Plant Cell 9, 13971409.

Piffanelli, P., Zhou, F.S., Casais, C., Orme, J., Jarosch, B., Schaffrath, U., Collins, N.C., Panstruga, R. and Schulze-Lefert, P. (2002) The barley MLO modulator of defense and cell death is responsive to biotic and abiotic stress stimuli. Plant Physiology 129, 1076-1085.

Planchon, J.E. (1887) Monographie des Ampelidae vraies. Monographia Phanerogamarum A et C de Candolle 5, 305-364. Pollefeys, P. and Bousquet, J. (2003) Molecular genetic diversity of the French-American grapevine hybrids cultivated in North America. Genome 46, 1037-1048.

Ridout, J., Skamnioti, P., Porritt, O., Sacristan, S., Jones, J.D.G. and Brown, J.K.M. (2006) Multiple avirulence paralogues in cereal powdery mildew fungi may contribute to parasite fitness and defeat of plant resistance. The Plant Cell 18, 2402-2414.

Robinson, S.P., Jacobs, A.K. and Dry, I.B. (1997) A class IV chitinase is highly expressed in grape berries during ripening. Plant Physiology 114, 771-778.

Rossi, M., Goggin, F.L., Milligan, S.B., Kaloshian, I., Ullman, D.E. and Williamson, V.M. (1998) The nematode resistance gene Mi of tomato confers resistance against the potato aphid. Proceedings of National Academy of Sciences U.S.A. 95, 9750-9754.

Santos-Rosa, M., Poutaraud, A., Merdinoglu, D. and Mestre, P. (2008) Developement of a transient expression system in grapevine via agro-infiltration. Plant Cell Reports 27, 10531063.

Savocchia, S., Stummer, B.E., Wicks, T.J., van Heeswijck, R. and Scott, E.S. (2004) Reduced sensitivity of Uncinula necator to sterol demethylation inhibiting fungicides in southern Australian vineyards. Australasian Plant Pathology 33, 465-473.

Shen, K.A., Meyers, B.C., Islam-Faridi, M.N., Chin, D.B., Stelly, D.M. and Michelmore, R.W. (1998) Resistance gene candidates identified by PCR with degenerate oligonucleotide primers map to clusters of resistance genes in lettuce. Molecular Plant Microbe Interactions 11, 815-823.

Srichumpa, P., Brunner, S., Keller, B. and Yahiaoui, N. (2005) Allelic series of four powdery mildew resistance genes at the Pm3 locus in hexaploid bread wheat. Plant Physiology 139, 885895.

Steffenson, B.J. (1992) Analysis of durable resistance to stem rust in barley. Euphytica 63, 153-167.

Stein, M., Dittgen, J., Sánchez-Rodriquez, C., Hou, B-H., Molina, A., Schulze-Lefert, P., Lipka, V. and Somerville, S. (2006) Arabidopsis PEN3/PDR8, an ATP binding cassette transporter, contributes to nonhost resistance to inappropriate pathogens that enter by direct penetration. The Plant Cell 18, 731-746.

Stummer, B.E., Francis, I.L., Zanker, T., Lattey, K.A. and Scott, E.S. (2005) Effects of powdery mildew on the sensory properties and composition of Chardonnay juice and wine when grape sugar ripeness is standardised. Australian Journal of Grape and Wine Research 11, 66-76. 
Takken, F.L.W., Albrecht, M. and Tameling, W.I.L. (2006) Resistance proteins: molecular switches of plant defence. Current Opinions in Plant Biology 9, 383-390.

Tao, Y., Yuan, F., Leister, R.T., Ausubel, F.M. and Katagiri, F. (2000) Mutational analysis of the Arabidopsis nucleotide binding site-leucine rich repeat resistance gene RPS2. The Plant Cell $\mathbf{1 2}$ 2541-2554.

Tattersall, D.B., van Heeswijck, R. and Hoj, P.B. (1997) Identification and characterization of a fruit-specific, thaumatin-like protein that accumulates at very high levels in conjunction with the onset of sugar accumulation and berry softening in grapes. Plant Physiology 114, 759-769.

This, P., Lacombe, T. and Thomas, M.R. (2006) Historical origins and genetic diversity of wine grapes. Trends in Genetics 22, 511519.

Wan, Y.Z., Schwaninger, H., He, P.C. and Wang, Y.J. (2007) Comparison of resistance to powdery mildew and downy mildew in Chinese wild grapes. Vitis 46, 132-136.

Welter, L.J., Göktürk-Baydar, N., Akkurt, M., Maul, E., Eibach, R. Töpfer, R. and Zyprian, E.M. (2007) Genetic mapping and localization of quantitative trait loci affecting fungal disease resistance and leaf morphology in grapevine (Vitis vinifera L). Molecular Breeding 20, 359-374.

Winterhagen, P., Howard, S.F., Qui, W. and Kovács, L.G. (2008) Transcriptional upregulation of grapevine MLO genes in response to powdery mildew infection. American Journal of Enology and Viticulture 59, 159-168.

Zhou, F., Kurth, J., Wei, F., Elliott, C., Valè, G., Yahiaoui, N., Keller, B., Somerville, S., Wise, R. and Schulze-Lefert, P. (2001) Cell-autonomous expression of barley Mlal confers race-specific resistance to the powdery mildew fungus via a Rarl-independent signaling pathway. The Plant Cell 13, 337-350.

Manuscript received: 9 February 2009

Revised manuscript received: 10 May 2009

Accepted: 20 May 2009 